\title{
Contamination and Risk Assessment of Heavy Metals in Lake Bed Sediment of a Large Lake Scenic Area in China
}

\author{
Li Wan ${ }^{1}$, Liang $\mathrm{Xu}^{2}$ and Yongsheng Fu ${ }^{1}$ ** \\ 1 Faculty of Geoscience and Environmental Engineering, Southwest Jiaotong University, No. 999 Xian Road, \\ Chengdu 611756, China; happyviny@126.com \\ 2 Jilin Institute of Chemical Technology, Jilin City 132022, China; suncaiyun1985@126.com \\ * Correspondence: fuyosh@163.com; Tel.: +86-139-0803-8700
}

Academic Editor: Kiran Tota-Maharaj

Received: 7 June 2016; Accepted: 14 July 2016; Published: 21 July 2016

\begin{abstract}
The exposure of heavy metals to lake bed sediment of scenic areas may pose risks on aquatic ecosystems and human health, however very few studies on risk assessment have been reported for scenic areas. Accordingly, this study determined concentration levels, and assessed contamination characteristics and risks, of heavy metals in lake bed sediment of National Scenic Areas Songhuahu (NSAS) in China. The concentrations of $\mathrm{Zn}, \mathrm{Cr}, \mathrm{Pb}, \mathrm{Ni}$, and $\mathrm{Cu}$ were determined in 29 bed sediment samples. Results showed that the mean values of $\mathrm{Zn}, \mathrm{Cr}, \mathrm{Pb}, \mathrm{Ni}$, and $\mathrm{Cu}$ were 92.69, 90.73, 38.29, 46.77, and $49.44 \mathrm{mg} / \mathrm{kg}$, respectively. Pearson correlation coefficients indicated that organic matter was a major factor influencing distribution of heavy metals. The results for enrichment factors indicated that contamination rates and anthropogenic inputs of single heavy metals decreased in the order $\mathrm{Cu}>\mathrm{Ni}>\mathrm{Pb}>\mathrm{Cr}>\mathrm{Zn}$; results of Nemerow integrated pollution index suggested that $72.41 \%$ of sampling sites were exposed to low to moderately integrated pollution, and $27.59 \%$ of sampling sites were exposed to strongly integrated pollution. According to results for potential ecological risk index, ecological risks of single and all the heavy metals in bed sediment from all the sampling sites were low. Human risks were assessed with hazardous quotients, and the results suggested that exposure of heavy metals to bed sediment posed no or little risk to human health, and the pathway of ingestion significantly contributed to human health risks.
\end{abstract}

Keywords: heavy metals; bed sediment; Songhua lake; ecological risk assessment; human health risk assessment

\section{Introduction}

The contamination of heavy metals in rivers or lakes has drawn increasing attention [1], as heavy metals have characteristics of potential toxicity, persistence, and non-biodegradation which pose potential risks on aquatic ecosystems and human health [2-4]. In an aquatic ecosystem, sediment is an important component, acting as a major sink for heavy metals due to their great tendency of adsorbing onto solid phases [5,6]. Thus, bed sediment is the main carrier of heavy metals in lakes or rivers [7] and is regarded as an effective indicator of heavy metal pollution [8,9]. However, once toxic levels of heavy metals are reached in organisms, diversity of benthic organisms and reproduction rates can decrease and growth rates can even be reduced [10,11], causing an adverse effect on aquatic ecosystems. In addition, heavy metals may enter and accumulate in the human body through ingestions or dermal contacts, and when toxic levels of heavy metals are reached in the human body, adverse effects are posed to human health.

Scenic areas are places that a large number of people visit, especially on national holidays. The exposure of pollutants in environmental media may have adverse effects to public health, but very 
few studies on contamination risk assessment of pollutants have been reported for the scenic areas. In this study, we selected National Scenic Area Songhuahu (NSAS) as the study area, as it is one of the most famous lake scenic areas in China. NSAS has a lake scenic area of 554 square kilometers and is located in Jilin City of China where the region is subjected to a semi-humid continental monsoon climate. The lake scenic area is long and narrow, and the maximum water-storage is 10.8 billion cubic meters. NSAS is fed by Songhua River. However, with rapid development of industry and urbanization, Songhua River has been receiving an increasing amount of industrial and domestic effluents, vehicular emissions, and wastewater produced by mining and refining activities [12-14], which may pose potential contamination risks of heavy metals on aquatic ecosystem of NSAS [15]. NSAS is famous for its lake scenery, and a large number of people visit every year. However, potential contamination of heavy metals in the aquatic environment may pose risks to human health and the aquatic ecosystem.

Contamination risk assessment of pollutants is fundamental for contamination control and management, so routinely monitoring concentrations of pollutants and evaluating contamination risks is essential [16]. Accordingly, the main aims of this work are to determine concentration levels of heavy metals in lake bed sediment of NSAS, evaluate contamination characteristics, and assess risks of heavy metals to the aquatic ecosystem and human health. This study will provide valuable information on contamination control and management.

\section{Materials and Methods}

NSAS - with a lake scenic area of 554 square kilometers-is located in Jilin City, Jilin Province of China, where the region is subjected to a semi-humid continental monsoon climate. The lake scenic area is long and narrow, and the maximum water-storage is 10.8 billion cubic meters. NSAS is fed by Songhua River where potential sources of heavy metals are located.

On 1-3 May 2016, a total of 29 bed sediment samples $(5-10 \mathrm{~cm})$ were collected to evaluate comprehensive pollution of heavy metals in the aquatic ecosystem; the sampling sites are represented in Figure 1. All the sampling sites are located along Songhua lake where a large number of tourists visit and sanatoriums and hotels are located. Sites 1 and 2 are located in the inflow-river area of Songhua lake, and site 29 is located in the outflow-river area of Songhua lake. Sites 3-10 are located in places where there are less anthropogenic activities, and sites 11-28 are located in developed-tourism areas. To reduce randomicity, each bed sediment sample was thoroughly mixed with three subsamples, and the distance of every two subsamples was at least one hundred meters away. Bed sediment samples were collected with an Ekman grab sampler, placed in polyethylene plastic bags, labeled, immediately transported to the lab, and kept under $4{ }^{\circ} \mathrm{C}$ until analyses were performed.
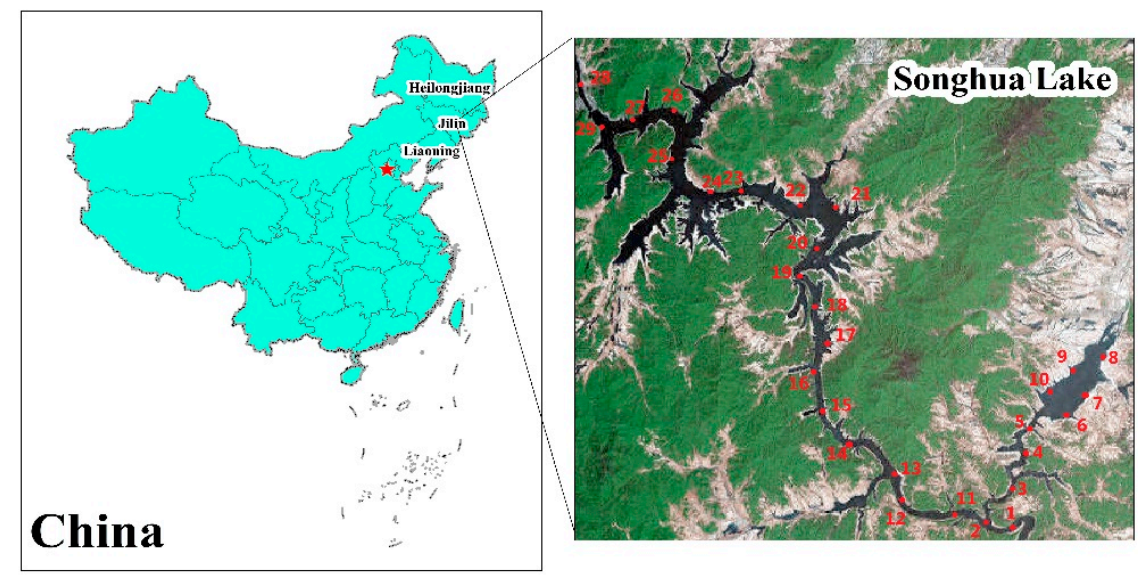

Figure 1. The locations of National Scenic Areas Songhuahu (NSAS) and sampling sites. 


\subsection{Sediment Analyses}

Each bed sediment sample was air dried, ground with a mortar, and passed through a 100-mesh sieve. Then, $1 \mathrm{~g}$ of pretreated sediment sample was digested with $\mathrm{HClO}_{4}-\mathrm{HNO}_{3}-\mathrm{HF}[17,18]$, and the concentrations of $\mathrm{Zn}, \mathrm{Cr}, \mathrm{Pb}, \mathrm{Ni}$, and $\mathrm{Cu}$ in the extracts were determined using an atom absorption spectrophotometer (Z-5000, HITACHI, Tokyo, Japan).

The values of sediment $\mathrm{pH}$ were measured (sediment:water 1:2.5 dry weight/volume) using a pH-meter (pHS-3B, Leici, Shanghai, China). Organic matter contents were determined by the Walkey-Black method [19].

\subsection{Quality Insurance}

Before pretreatment of bed sediment samples, the recovery rates for heavy metals were conducted. The results showed that recovery rates were $93 \%-99 \%$ for $\mathrm{Zn}, 92 \%-110 \%$ for $\mathrm{Cr}, 90 \%-105 \%$ for $\mathrm{Pb}$, $88 \%-97 \%$ for $\mathrm{Ni}$, and $93 \%-109 \%$ for $\mathrm{Cu}$. All the chemical analyses and control experiments were conducted in duplicate, and the standard deviations were all within $\pm 5 \%$.

\subsection{Data Analysis}

\subsubsection{Enrichment Factors}

This study applied enrichment factors (EFs) to characterize the contamination rates and assess anthropogenic inputs of single heavy metals [20]. The values of EFs were calculated with Equation (1):

$$
\mathrm{EFs}=\left(\mathrm{C}_{\mathrm{n}} / \mathrm{B}_{\mathrm{n}}-1\right) \times 100
$$

where $C_{n}$ is the monitoring concentration of specific heavy metal in bed sediment; $B_{n}$ is background concentration of specific heavy metal in bed sediment. The background concentrations were obtained from a published article [21]. The values of EFs $\leqslant 0$ indicate no anthropogenic inputs of heavy metals in bed sediment samples, and the values of EFs $>0$ indicate anthropogenic inputs of heavy metals in bed sediment samples.

\subsubsection{Nemerow Integrated Pollution Index}

To evaluate integrated contamination characteristics of all the heavy metals in bed sediment, Nemerow integrated pollution $\left(P_{n}\right)$ index was applied. $P_{n}$ was expressed as Equation (3), and the $P_{n}$ levels are illustrated as Table 1 [22].

$$
\begin{gathered}
\mathrm{P}_{\mathrm{i}}=\mathrm{C}_{\mathrm{i}} / \mathrm{B}_{\mathrm{i}} \\
\mathrm{P}_{\mathrm{n}}=\left\{\left[\left(\mathrm{P}_{\text {iav }}\right)^{2}+\left(\mathrm{P}_{\text {imax }}\right)^{2}\right] / 2\right\}^{1 / 2}
\end{gathered}
$$

where $C_{i}$ is the monitoring concentration of specific heavy metal; $B_{i}$ is the background concentration of specific value; $P_{i a v}$ is the average value of single pollution indexes for all the heavy metals; $P_{i m a x}$ is the maximum value of the single pollution indexes for all the heavy metals [23].

Table 1. Illustration Nemerow integrated pollution $\left(P_{n}\right)$ levels related to sediment quality.

\begin{tabular}{ccc}
\hline Values of $\mathbf{P}_{\mathbf{n}}$ & Level of $\mathbf{P}_{\mathbf{n}}$ & Sediment Quality \\
\hline $0-0.7$ & 1 & Unpolluted \\
$0.7-1$ & 2 & Warning limit \\
$1-2$ & 3 & Low polluted \\
$2-3$ & 4 & Moderately polluted \\
$>3$ & 5 & Strongly polluted \\
\hline
\end{tabular}




\subsubsection{Potential Ecological Risk Index}

In this study, the potential ecological risk index (PERI) was applied to evaluate potential ecological risks (ER) of single heavy metals and all the heavy metals [24]. The values of ER for single heavy metals and values of PERI for all the heavy metals were respectively calculated as Equations (4) and (5):

$$
\begin{aligned}
\mathrm{ER} & =\mathrm{Ti} \times \mathrm{C}_{\mathrm{i} 0} / \mathrm{B}_{\mathrm{in}} \\
\mathrm{PERI} & =\sum \mathrm{Ti} \times \mathrm{C}_{\mathrm{i} 0} / \mathrm{B}_{\mathrm{i}}
\end{aligned}
$$

where $C_{i 0}$ is the monitoring concentration of specific heavy metal in bed sediment; $B_{\text {in }}$ is the background concentration of specific heavy metal in bed sediment; and $\mathrm{T}_{\mathrm{i}}$ is the toxic-response factor for specific heavy metal, where the values for $\mathrm{Zn}, \mathrm{Cr}, \mathrm{Pb}, \mathrm{Ni}$, and $\mathrm{Cu}$ are 1, 2, 5, 5, and 5, respectively. The potential ecological risk levels for single heavy metals are regarded as follows: low risk $(\mathrm{ER}<40)$, moderate risk $(40 \leqslant \mathrm{ER}<80)$, considerable risk $(80 \leqslant \mathrm{ER}<160)$, high risk $(160 \leqslant \mathrm{ER}<320)$, and very high risk $(E R \geqslant 320)$. The potential comprehensive ecological risk levels for all the heavy metals are regarded as follows: low ecological risk (PERI < 150), moderate ecological risk $(150 \leqslant$ PERI < 300), considerable ecological risk ( $300 \leqslant$ PERI $<600)$, and very high ecological risk (PERI $\geqslant 600)$ [6].

\subsubsection{Human Health Risk Assessment}

In general, the major pathways of ingestion and dermal contact are considered in human health risk assessment [25]. The exposures through ingestion and dermal contact were respectively calculated using Equations (6) and (7):

$$
\begin{gathered}
\operatorname{Exp}_{\text {ing }}=\left(\mathrm{C}_{\mathrm{i}} \times \mathrm{IR} \times \mathrm{CF} \times \mathrm{EF} \times \mathrm{ED}\right) /(\mathrm{BW} \times \mathrm{AT}) \\
\operatorname{Exp}_{\text {der }}=\left(\mathrm{C}_{\mathrm{i}} \times \mathrm{CF} \times \mathrm{SA} \times \mathrm{AF} \times \mathrm{ABS} \times \mathrm{EF} \times \mathrm{ED}\right) /(\mathrm{BW} \times \mathrm{AT})
\end{gathered}
$$

where Exp $p_{\text {ing }}$ is the exposure of ingestion from sediment; $C_{i}$ is the monitoring concentration of a specific heavy metal in the bed sediment; $\mathrm{IR}$ is the ingestion rate (114 $\mathrm{mg} /$ day); $\mathrm{CF}$ is the unit conversion factor $\left(10^{-6} \mathrm{~kg} / \mathrm{mg}\right.$ ); $\mathrm{EF}$ is the exposure frequency (350 days/year); $\mathrm{ED}$ is the exposure duration (30 years); BW is the body weight $(70 \mathrm{~kg})$; AT is the average day $\left(10,950\right.$ days); $\operatorname{Exp}_{\text {der }}$ is the exposure of dermal contacts from sediment; SA is the exposed skin surface area $\left(5700 \mathrm{~cm}^{2}\right)$; AF is the adherence factor from sediment to skin $\left(0.07 \mathrm{mg} / \mathrm{cm}^{2}\right)$; and ABS is the dermal absorption from sediment $(0.001)$.

Hazardous quotients (HQs) were applied to assess noncarcinogenic risks of heavy metals in bed sediment [26]. The values of HQs for pathways of ingestion and dermal contact were respectively calculated according to Equations (8) and (9):

$$
\begin{gathered}
\mathrm{HQ}_{\text {ing } / \text { der }}=\mathrm{Exp}_{\text {ing } / \mathrm{der}} / \mathrm{RfD} \\
\mathrm{HI}=\sum \mathrm{HQ}_{\text {ing } / \text { der }}
\end{gathered}
$$

where RfD is the reference value for causing adverse effects on human health by specific heavy metal. The reference values for dermal contact are considered to be identical to the reference values for ingestion of heavy metals in sediment [27]. $\mathrm{HQ}_{\text {ing/der }}<1$ indicates that exposure of heavy metals to sediment may pose no or little risks on human health; $\mathrm{HQ}_{\mathrm{ing} / \mathrm{der}}>1$ indicates that exposure of heavy metals to sediment may pose risks on human health [28].

\section{Results}

\subsection{Occurrence of Heavy Metals in Bed Sediment}

Table 2 represents descriptive statistics of heavy metal concentrations in bed sediment of NSAS; the concentrations of $\mathrm{Zn}, \mathrm{Cr}, \mathrm{Pb}, \mathrm{Ni}$, and $\mathrm{Cu}$ were analyzed. The results showed that all five heavy 
metals were detected in all the samples, and the mean values of $\mathrm{Zn}, \mathrm{Cr}, \mathrm{Pb}, \mathrm{Ni}$, and $\mathrm{Cu}$ were 92.69, $90.73,38.29,46.77$, and $49.44 \mathrm{mg} / \mathrm{kg}$, respectively. The mean concentrations of these five heavy metals all exceeded the corresponding background concentrations. The values of coefficients of variation for five heavy metals varied from $28.85 \%$ for $\mathrm{Zn}$ to $54.21 \%$ for $\mathrm{Cu}$.

Table 2. Descriptive statistics of heavy metal concentrations in bed sediment of National Scenic Area Songhuahu (NSAS).

\begin{tabular}{|c|c|c|c|c|c|c|c|}
\hline & $\mathrm{Zn}$ (mg/kg) & $\mathrm{Cr}(\mathrm{mg} / \mathrm{kg})$ & $\mathrm{Pb}(\mathrm{mg} / \mathrm{kg})$ & $\mathrm{Ni}(\mathrm{mg} / \mathrm{kg})$ & $\mathrm{Cu}(\mathrm{mg} / \mathrm{kg})$ & $\mathrm{pH}$ & ${ }^{\mathrm{c}} \mathrm{OM}(\%)$ \\
\hline $\min$ & 55.53 & 34.12 & 15.96 & 13.42 & 15.74 & 5.46 & 2.35 \\
\hline $\max$ & 171.32 & 187.02 & 72.85 & 99.05 & 128.94 & 8.91 & 5.7 \\
\hline mean & 92.69 & 90.73 & 38.29 & 46.77 & 49.44 & 7.39 & 3.97 \\
\hline a CV (\%) & 28.85 & 39.71 & 38.22 & 48.38 & 54.21 & 12.99 & 21.46 \\
\hline${ }^{\mathrm{b}} \mathrm{BC}$ & 59.47 & 50.17 & 20.46 & 23.07 & 17.96 & & \\
\hline
\end{tabular}

Physicochemical parameters, sediment $\mathrm{pH}$, and organic matter $(\mathrm{OM})$ contents were measured. The values of sediment $\mathrm{pH}$ ranged from 5.46 to 8.91 with a mean value of 7.39. Most sediment samples were neutral, with 13 sediment samples of the soils having $\mathrm{pH}$ values between 7 and 8 , eight sediment samples having $\mathrm{pH}$ values below 7 , and eight sediment samples having $\mathrm{pH}$ values above 8 . Organic matter contents ranged from $2.35 \%$ to $5.7 \%$ with a mean value of $3.97 \%$. The correlations between heavy metals and sediment $\mathrm{pH}$ and physicochemical parameters were evaluated with Pearson correlation coefficients. As represented in Table 3, the correlations between heavy metals and $\mathrm{pH}$ were weak; the correlations between most of the heavy metals and OM were strongly positive.

Table 3. Pearson correlations between heavy metals and physicochemical parameters.

\begin{tabular}{ccc}
\hline & $\mathbf{p H}$ & $\mathbf{O M}$ \\
\cline { 2 - 3 } $\mathrm{Zn}$ & -0.186 & $0.387^{*}$ \\
$\mathrm{Cr}$ & 0.038 & 0.286 \\
$\mathrm{~Pb}$ & 0.119 & 0.343 \\
$\mathrm{Ni}$ & -0.275 & $0.374^{*}$ \\
$\mathrm{Cu}$ & 0.071 & $0.454^{*}$ \\
\cline { 2 - 3 } * Denotes that correlation is significant at the 0.05 level (2-tailed).
\end{tabular}

\subsection{Contamination Characteristics and Risk Assessment}

\subsubsection{Enrichment Factors}

EFs were applied to characterize contamination rates and assess anthropogenic inputs of single heavy metals. As represented in Table 4, most values of EFs for five heavy metals in different sampling sites were greater than zero. The values of EFs for $\mathrm{Zn}$ ranged from $-6.63 \%$ to $188.08 \%$ with a mean value of $55.87 \%$; the values of EFs for Cr ranged from $-31.99 \%$ to $272.77 \%$ with a mean value of $80.85 \%$; the values of $\mathrm{EFs}$ for $\mathrm{Pb}$ ranged from $-22.02 \%$ to $255.94 \%$ with a mean value of $87.09 \%$; the values of EFs for Ni ranged from $-41.83 \%$ to $329.35 \%$ with a mean value of $102.72 \%$; and the values of EFs for $\mathrm{Cu}$ ranged from $-12.39 \%$ to $617.65 \%$ with a mean value of $175.19 \%$. 
Table 4. The values of enrichment factors (EFs; \%) for five heavy metals in bed sediment of NSAS.

\begin{tabular}{|c|c|c|c|c|c|}
\hline Sampling Site & $\mathrm{Zn}$ & $\mathrm{Cr}$ & $\mathrm{Pb}$ & $\mathbf{N i}$ & $\mathrm{Cu}$ \\
\hline 1 & 150.93 & 272.77 & 107.46 & 274.64 & 374.98 \\
\hline 2 & 188.08 & 194.04 & 119.62 & 329.35 & 617.65 \\
\hline 3 & 104.04 & 201.97 & 7.25 & 137.75 & 446.61 \\
\hline 4 & 30.35 & 73.89 & 152.70 & 19.77 & 211.29 \\
\hline 5 & 83.15 & 113.73 & 9.98 & -0.95 & 113.84 \\
\hline 6 & 9.87 & 33.43 & 36.85 & 80.19 & -3.04 \\
\hline 7 & 26.84 & 68.01 & -22.02 & -35.85 & 210.68 \\
\hline 8 & -6.63 & 81.06 & 33.97 & 67.45 & 75.21 \\
\hline 9 & 5.43 & 12.60 & 12.08 & 6.07 & -12.39 \\
\hline 10 & 19.74 & -31.99 & -12.93 & -41.83 & 58.57 \\
\hline 11 & 59.64 & 58.28 & 26.25 & 115.56 & 86.62 \\
\hline 12 & 75.26 & 142.73 & 104.82 & 59.60 & 131.81 \\
\hline 13 & 26.69 & 215.77 & 176.98 & 7.02 & 317.10 \\
\hline 14 & 50.36 & 67.31 & 152.75 & 71.30 & 359.95 \\
\hline 15 & 13.01 & 84.19 & 16.33 & 50.93 & 80.78 \\
\hline 16 & 47.18 & 30.40 & 85.42 & 284.14 & 295.78 \\
\hline 17 & 89.04 & 54.02 & 255.94 & 85.26 & 65.25 \\
\hline 18 & 29.34 & 39.98 & 103.45 & 146.34 & 30.96 \\
\hline 19 & 48.24 & 2.91 & 133.74 & 2.43 & 163.04 \\
\hline 20 & 3.28 & 48.02 & 119.13 & 19.20 & 321.22 \\
\hline 21 & 77.27 & 13.39 & 33.97 & 235.59 & 124.30 \\
\hline 22 & 100.99 & 53.94 & 85.91 & 178.67 & 79.11 \\
\hline 23 & 43.33 & 89.75 & 7.20 & 67.88 & 48.83 \\
\hline 24 & 29.65 & 94.40 & 55.13 & 104.55 & 224.87 \\
\hline 25 & 40.42 & 53.82 & 83.32 & 80.75 & 117.51 \\
\hline 26 & 108.95 & 74.05 & 229.46 & 234.50 & 22.11 \\
\hline 27 & 86.33 & 5.06 & 143.42 & 86.17 & 146.56 \\
\hline 28 & 36.59 & 22.24 & 152.99 & 194.06 & 277.86 \\
\hline 29 & 42.85 & 174.95 & 114.54 & 118.34 & 93.41 \\
\hline $\operatorname{Max}$ & 188.08 & 272.77 & 255.94 & 329.35 & 617.65 \\
\hline Min & -6.63 & -31.99 & -22.02 & -41.83 & -12.39 \\
\hline Mean & 55.87 & 80.85 & 87.09 & 102.72 & 175.19 \\
\hline
\end{tabular}

\subsubsection{Nemerow Integrated Pollution Index}

To evaluate integrated pollution levels of all the heavy metals, $P_{n}$ index was employed. Figure 2 indicates integrated pollution levels of all the heavy metals in different sampling sites. The values of $P_{n}$ ranged from 1.09 to 5.77. The values of $P_{n}$ in nine sampling sites were between 1 and 2; the values of $P_{n}$ in twelve sampling sites ranged from 2 to 3 ; the values of $P_{n}$ in eight sampling sites were greater than 3. The highest values of $P_{n}$ occurred in sites 1 and 2, while the lowest values occurred in sites 9 and 10 .

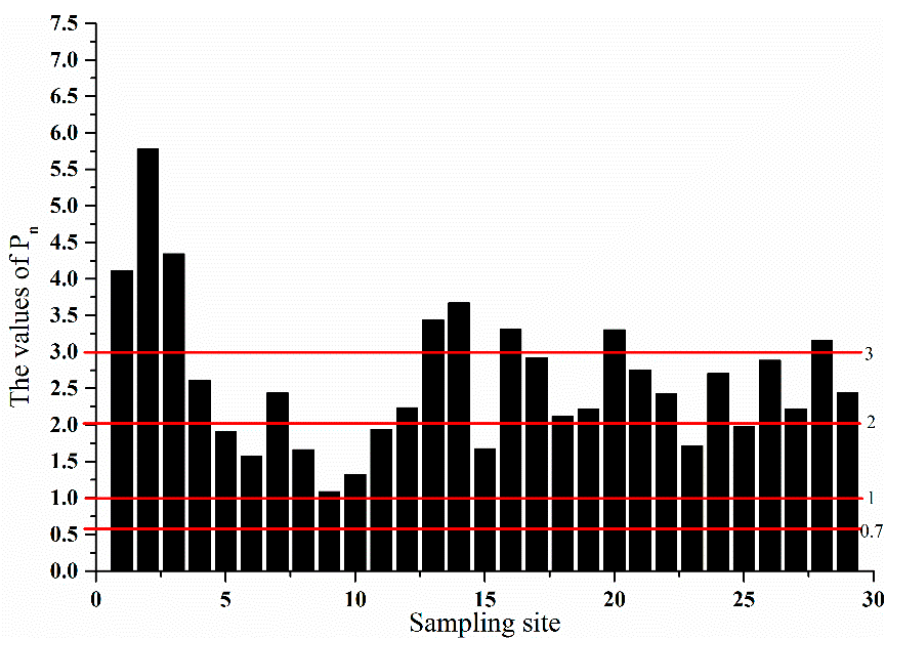

Figure 2. The Nemerow integrated pollution $\left(P_{n}\right)$ values of five heavy metals in different sampling sites. 


\subsubsection{Ecological Risk Assessment}

In this work, PERI was used to assess ecological risks of all the heavy metals and single heavy metals in different sampling sites. As represented in Figure 3, the values of ER for five heavy metals in all the sampling sites were smaller than 40.

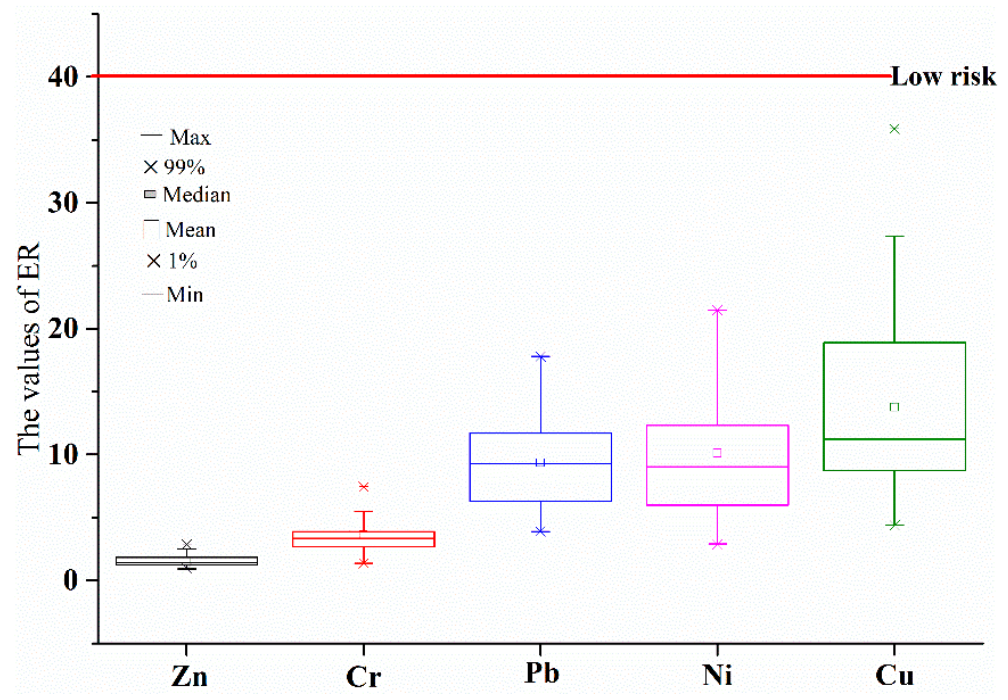

Figure 3. The ecological risks (ER) of single heavy metals in different sampling sites.

Figure 4 indicates comprehensive ecological risks of all the heavy metals in different sampling sites. The values of PERI in all the sampling sites were smaller than 150. Among 29 sampling sites, the comprehensive ecological risks of all the heavy metals were the lowest in sites 9 and 10, whereas the highest comprehensive ecological risks existed in sites 1 and 2 . The comprehensive ecological risk in site 28 was relatively higher, but the value of PERI in site 28 was below 150 .

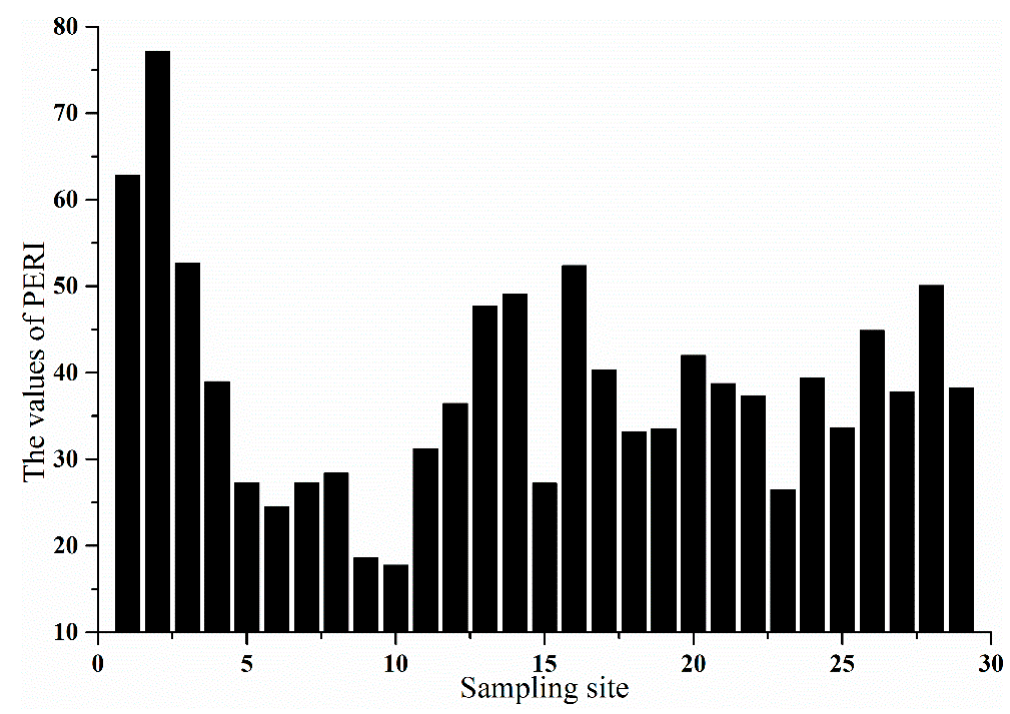

Figure 4. The values of potential ecological risk index (PERI) in different sampling sites.

\subsubsection{Human Health Risk Assessment}

Human health risk assessment was conducted with hazardous quotients (HQs) and the results are represented in Table 5. Hazardous index (HI) is the sum of HQ. The values of $\mathrm{HI}$ in all the sampling 
sites were smaller than 1 . The values of HQs for exposure of each heavy metal through pathways of ingestion and dermal contact to bed sediment from all the sampling sites were smaller than 1 . As represented in Figure 5A,B, among five heavy metals, the values of HQs for ingestion and dermal contact both decreased in the order $\mathrm{Cr}>\mathrm{Pb}>\mathrm{Ni}>\mathrm{Cu}>\mathrm{Zn}$. The values of HQs for exposures of all the heavy metals through ingestion were two or three orders of magnitude higher than through dermal contact.

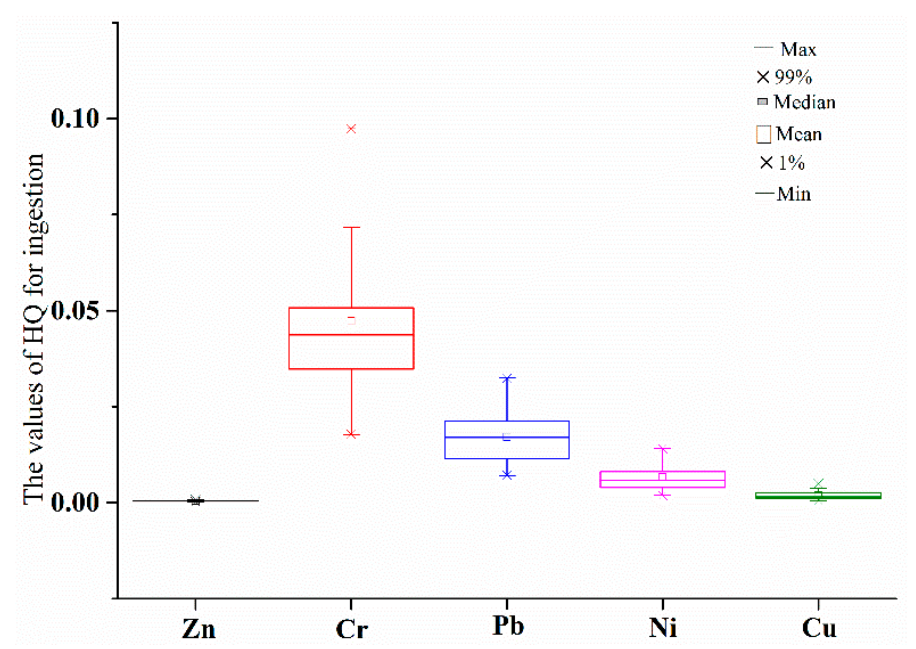

(A)

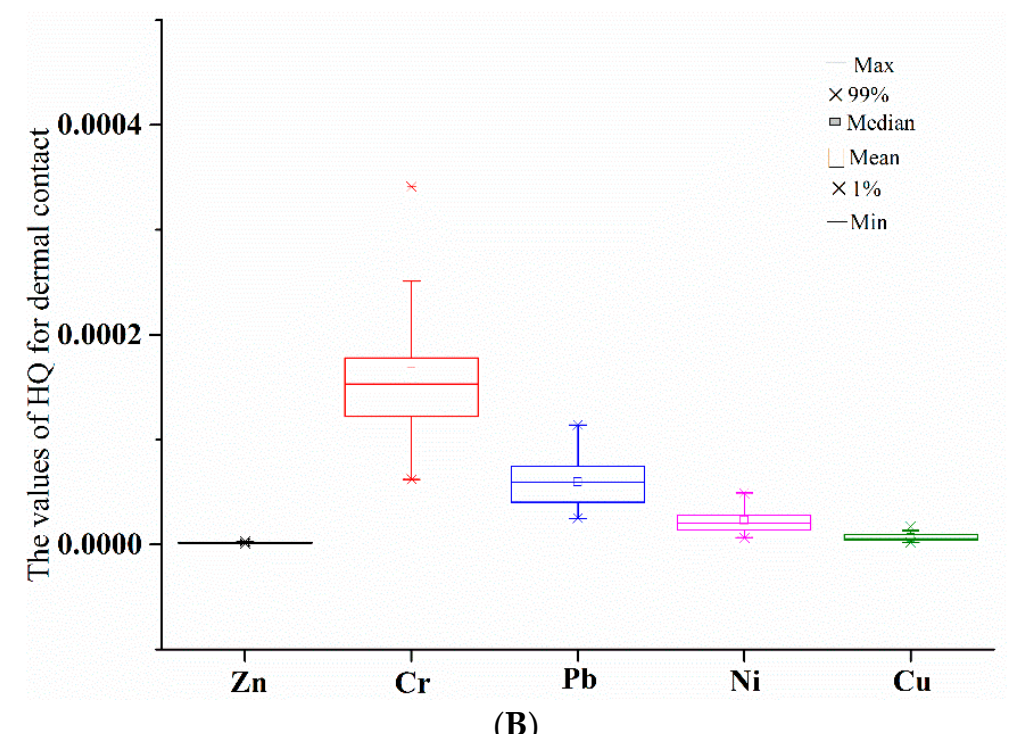

Figure 5. Human health risks of single heavy metals posed through pathways of ingestion (A) and dermal contact (B). HQ, hazardous quotient. 
Table 5. Human health risks of five heavy metals in bed sediment of National Scenic Area Songhuahu (NSAS).

\begin{tabular}{|c|c|c|c|c|c|c|c|c|c|c|c|}
\hline Sampling & Ingestion & & & & & Dermal & & & & & $\mathrm{HI}$ \\
\hline Site & $\mathrm{Zn}$ & $\mathrm{Cr}$ & $\mathrm{Pb}$ & $\mathrm{Ni}$ & $\mathrm{Cu}$ & $\mathrm{Zn}$ & $\mathrm{Cr}$ & $\mathrm{Pb}$ & $\mathrm{Ni}$ & $\mathrm{Cu}$ & \\
\hline 1 & $7.77 \times 10^{-4}$ & $9.74 \times 10^{-2}$ & $1.89 \times 10^{-2}$ & $1.23 \times 10^{-2}$ & $3.33 \times 10^{-3}$ & $2.72 \times 10^{-6}$ & $3.41 \times 10^{-4}$ & $6.63 \times 10^{-5}$ & $4.29 \times 10^{-5}$ & $1.17 \times 10^{-5}$ & $1.33 \times 10^{-1}$ \\
\hline 2 & $8.92 \times 10^{-4}$ & $7.68 \times 10^{-2}$ & $2.01 \times 10^{-2}$ & $1.41 \times 10^{-2}$ & $5.03 \times 10^{-3}$ & $3.12 \times 10^{-6}$ & $2.69 \times 10^{-4}$ & $7.02 \times 10^{-5}$ & $4.92 \times 10^{-5}$ & $1.76 \times 10^{-5}$ & $1.17 \times 10^{-1}$ \\
\hline 3 & $6.32 \times 10^{-4}$ & $7.89 \times 10^{-2}$ & $9.79 \times 10^{-3}$ & $7.79 \times 10^{-3}$ & $3.83 \times 10^{-3}$ & $2.21 \times 10^{-6}$ & $2.76 \times 10^{-4}$ & $3.43 \times 10^{-5}$ & $2.73 \times 10^{-5}$ & $1.34 \times 10^{-5}$ & $1.01 \times 10^{-1}$ \\
\hline 4 & $4.04 \times 10^{-4}$ & $4.54 \times 10^{-2}$ & $2.31 \times 10^{-2}$ & $3.92 \times 10^{-3}$ & $2.18 \times 10^{-3}$ & $1.41 \times 10^{-6}$ & $1.59 \times 10^{-4}$ & $8.08 \times 10^{-5}$ & $1.37 \times 10^{-5}$ & $7.64 \times 10^{-6}$ & $7.53 \times 10^{-2}$ \\
\hline 5 & $5.67 \times 10^{-4}$ & $5.58 \times 10^{-2}$ & $1.00 \times 10^{-2}$ & $3.24 \times 10^{-3}$ & $1.50 \times 10^{-3}$ & $1.98 \times 10^{-6}$ & $1.95 \times 10^{-4}$ & $3.52 \times 10^{-5}$ & $1.14 \times 10^{-5}$ & $5.25 \times 10^{-6}$ & $7.14 \times 10^{-2}$ \\
\hline 6 & $3.40 \times 10^{-4}$ & $3.48 \times 10^{-2}$ & $1.25 \times 10^{-2}$ & $5.90 \times 10^{-3}$ & $6.80 \times 10^{-4}$ & $1.19 \times 10^{-6}$ & $1.22 \times 10^{-4}$ & $4.37 \times 10^{-5}$ & $2.07 \times 10^{-5}$ & $2.38 \times 10^{-6}$ & $5.45 \times 10^{-2}$ \\
\hline 7 & $3.93 \times 10^{-4}$ & $4.39 \times 10^{-2}$ & $7.12 \times 10^{-3}$ & $2.10 \times 10^{-3}$ & $2.18 \times 10^{-3}$ & $1.37 \times 10^{-6}$ & $1.54 \times 10^{-4}$ & $2.49 \times 10^{-5}$ & $7.35 \times 10^{-6}$ & $7.63 \times 10^{-6}$ & $5.59 \times 10^{-2}$ \\
\hline 8 & $2.89 \times 10^{-4}$ & $4.7 \times 10^{-2}$ & $1.22 \times 10^{-2}$ & $5.4 \times 10^{-3}$ & $1.23 \times 10^{-3}$ & $1.01 \times 10^{-6}$ & $1.66 \times 10^{-4}$ & $4.28 \times 10^{-5}$ & $1.92 \times 10^{-5}$ & $4.30 \times 10^{-6}$ & $6.68 \times 10^{-2}$ \\
\hline 9 & $3.26 \times 10^{-4}$ & $2.94 \times 10^{-2}$ & $1.02 \times 10^{-2}$ & $3.47 \times 10^{-3}$ & $6.15 \times 10^{-4}$ & $1.14 \times 10^{-6}$ & $1.03 \times 10^{-4}$ & $3.58 \times 10^{-5}$ & $1.22 \times 10^{-5}$ & $2.15 \times 10^{-6}$ & $4.42 \times 10^{-2}$ \\
\hline 10 & $3.71 \times 10^{-4}$ & $1.78 \times 10^{-2}$ & $7.95 \times 10^{-3}$ & $1.91 \times 10^{-3}$ & $1.11 \times 10^{-3}$ & $1.30 \times 10^{-6}$ & $6.22 \times 10^{-5}$ & $2.78 \times 10^{-5}$ & $6.67 \times 10^{-5}$ & $3.89 \times 10^{-6}$ & $2.92 \times 10^{-2}$ \\
\hline 11 & $4.94 \times 10^{-4}$ & $4.13 \times 10^{-2}$ & $1.15 \times 10^{-2}$ & $7.06 \times 10^{-3}$ & $1.31 \times 10^{-3}$ & $1.73 \times 10^{-6}$ & $1.45 \times 10^{-4}$ & $4.04 \times 10^{-5}$ & $2.47 \times 10^{-5}$ & $4.58 \times 10^{-6}$ & $6.19 \times 10^{-2}$ \\
\hline 12 & $5.43 \times 10^{-4}$ & $6.34 \times 10^{-2}$ & $1.87 \times 10^{-2}$ & $5.23 \times 10^{-3}$ & $1.63 \times 10^{-3}$ & $1.90 \times 10^{-6}$ & $2.22 \times 10^{-4}$ & $6.55 \times 10^{-5}$ & $1.83 \times 10^{-5}$ & $5.69 \times 10^{-6}$ & $8.98 \times 10^{-2}$ \\
\hline 13 & $3.92 \times 10^{-4}$ & $8.25 \times 10^{-2}$ & $2.53 \times 10^{-2}$ & $3.51 \times 10^{-3}$ & $2.93 \times 10^{-3}$ & $1.37 \times 10^{-6}$ & $2.89 \times 10^{-4}$ & $8.85 \times 10^{-5}$ & $1.23 \times 10^{-5}$ & $1.02 \times 10^{-6}$ & $1.15 \times 10^{-1}$ \\
\hline 14 & $4.65 \times 10^{-4}$ & $4.37 \times 10^{-2}$ & $2.31 \times 10^{-2}$ & $5.61 \times 10^{-3}$ & $3.23 \times 10^{-3}$ & $1.63 \times 10^{-6}$ & $1.53 \times 10^{-4}$ & $8.08 \times 10^{-5}$ & $1.96 \times 10^{-5}$ & $1.13 \times 10^{-6}$ & $7.63 \times 10^{-2}$ \\
\hline 15 & $3.50 \times 10^{-4}$ & $4.81 \times 10^{-2}$ & $1.06 \times 10^{-2}$ & $4.94 \times 10^{-3}$ & $1.27 \times 10^{-3}$ & $1.22 \times 10^{-6}$ & $1.68 \times 10^{-4}$ & $3.72 \times 10^{-5}$ & $1.73 \times 10^{-5}$ & $4.44 \times 10^{-6}$ & $6.55 \times 10^{-2}$ \\
\hline 16 & $4.56 \times 10^{-4}$ & $3.41 \times 10^{-2}$ & $1.69 \times 10^{-2}$ & $1.26 \times 10^{-2}$ & $2.78 \times 10^{-3}$ & $1.59 \times 10^{-6}$ & $1.19 \times 10^{-4}$ & $5.93 \times 10^{-5}$ & $4.40 \times 10^{-5}$ & $9.72 \times 10^{-6}$ & $6.70 \times 10^{-2}$ \\
\hline 17 & $5.85 \times 10^{-4}$ & $4.02 \times 10^{-2}$ & $3.25 \times 10^{-2}$ & $6.07 \times 10^{-3}$ & $1.16 \times 10^{-3}$ & $2.05 \times 10^{-6}$ & $1.41 \times 10^{-4}$ & $1.14 \times 10^{-5}$ & $2.12 \times 10^{-5}$ & $4.06 \times 10^{-6}$ & $8.08 \times 10^{-2}$ \\
\hline 18 & $4.00 \times 10^{-4}$ & $3.66 \times 10^{-2}$ & $1.86 \times 10^{-2}$ & $8.07 \times 10^{-3}$ & $9.19 \times 10^{-4}$ & $1.40 \times 10^{-6}$ & $1.28 \times 10^{-4}$ & $6.50 \times 10^{-5}$ & $2.82 \times 10^{-5}$ & $3.22 \times 10^{-6}$ & $6.48 \times 10^{-2}$ \\
\hline 19 & $4.59 \times 10^{-4}$ & $2.69 \times 10^{-2}$ & $2.13 \times 10^{-2}$ & $3.35 \times 10^{-3}$ & $1.85 \times 10^{-3}$ & $1.61 \times 10^{-6}$ & $9.41 \times 10^{-4}$ & $7.47 \times 10^{-5}$ & $1.17 \times 10^{-5}$ & $6.46 \times 10^{-6}$ & $5.41 \times 10^{-2}$ \\
\hline 20 & $3.20 \times 10^{-4}$ & $3.87 \times 10^{-2}$ & $2.00 \times 10^{-2}$ & $3.90 \times 10^{-3}$ & $2.95 \times 10^{-3}$ & $1.12 \times 10^{-6}$ & $1.35 \times 10^{-4}$ & $7.00 \times 10^{-5}$ & $1.37 \times 10^{-5}$ & $1.03 \times 10^{-6}$ & $6.61 \times 10^{-2}$ \\
\hline 21 & $5.49 \times 10^{-4}$ & $2.96 \times 10^{-2}$ & $1.22 \times 10^{-2}$ & $1.10 \times 10^{-2}$ & $1.57 \times 10^{-3}$ & $1.92 \times 10^{-6}$ & $1.04 \times 10^{-4}$ & $4.28 \times 10^{-5}$ & $3.85 \times 10^{-5}$ & $5.51 \times 10^{-6}$ & $5.52 \times 10^{-2}$ \\
\hline 22 & $6.22 \times 10^{-4}$ & $4.02 \times 10^{-2}$ & $1.70 \times 10^{-2}$ & $9.13 \times 10^{-3}$ & $1.26 \times 10^{-3}$ & $2.18 \times 10^{-6}$ & $1.41 \times 10^{-4}$ & $5.94 \times 10^{-5}$ & $3.19 \times 10^{-5}$ & $4.40 \times 10^{-6}$ & $6.84 \times 10^{-2}$ \\
\hline 23 & $4.44 \times 10^{-4}$ & $4.96 \times 10^{-2}$ & $9.79 \times 10^{-3}$ & $5.50 \times 10^{-3}$ & $1.04 \times 10^{-3}$ & $1.55 \times 10^{-6}$ & $1.73 \times 10^{-4}$ & $3.43 \times 10^{-5}$ & $1.92 \times 10^{-5}$ & $3.65 \times 10^{-6}$ & $6.66 \times 10^{-2}$ \\
\hline 24 & $4.01 \times 10^{-4}$ & $5.08 \times 10^{-2}$ & $1.42 \times 10^{-2}$ & $6.70 \times 10^{-3}$ & $2.28 \times 10^{-3}$ & $1.40 \times 10^{-6}$ & $1.78 \times 10^{-4}$ & $4.96 \times 10^{-5}$ & $2.34 \times 10^{-5}$ & $7.98 \times 10^{-6}$ & $7.46 \times 10^{-2}$ \\
\hline 25 & $4.35 \times 10^{-4}$ & $4.02 \times 10^{-2}$ & $1.67 \times 10^{-2}$ & $5.92 \times 10^{-3}$ & $1.53 \times 10^{-3}$ & $1.52 \times 10^{-6}$ & $1.41 \times 10^{-4}$ & $5.86 \times 10^{-5}$ & $2.07 \times 10^{-5}$ & $5.34 \times 10^{-6}$ & $6.50 \times 10^{-2}$ \\
\hline 26 & $6.47 \times 10^{-4}$ & $4.55 \times 10^{-2}$ & $3.01 \times 10^{-2}$ & $1.10 \times 10^{-2}$ & $8.57 \times 10^{-4}$ & $2.26 \times 10^{-6}$ & $1.59 \times 10^{-4}$ & $1.05 \times 10^{-4}$ & $3.83 \times 10^{-5}$ & $3.00 \times 10^{-6}$ & $8.83 \times 10^{-2}$ \\
\hline 27 & $5.77 \times 10^{-4}$ & $2.74 \times 10^{-2}$ & $2.22 \times 10^{-2}$ & $6.10 \times 10^{-3}$ & $1.73 \times 10^{-3}$ & $2.02 \times 10^{-6}$ & $9.60 \times 10^{-4}$ & $7.78 \times 10^{-5}$ & $2.13 \times 10^{-5}$ & $6.05 \times 10^{-6}$ & $5.83 \times 10^{-2}$ \\
\hline 28 & $4.23 \times 10^{-4}$ & $3.19 \times 10^{-2}$ & $2.31 \times 10^{-2}$ & $9.63 \times 10^{-3}$ & $2.65 \times 10^{-3}$ & $1.48 \times 10^{-6}$ & $1.12 \times 10^{-4}$ & $8.09 \times 10^{-5}$ & $3.37 \times 10^{-5}$ & $9.28 \times 10^{-6}$ & $6.80 \times 10^{-2}$ \\
\hline 29 & $4.42 \times 10^{-4}$ & $7.18 \times 10^{-2}$ & $1.96 \times 10^{-2}$ & $7.15 \times 10^{-3}$ & $1.36 \times 10^{-3}$ & $1.55 \times 10^{-6}$ & $2.51 \times 10^{-4}$ & $6.86 \times 10^{-5}$ & $2.50 \times 10^{-5}$ & $4.75 \times 10^{-6}$ & $1.01 \times 10^{-2}$ \\
\hline
\end{tabular}

HI, hazardous index. 


\section{Discussion}

\subsection{Heavy Metals in Bed Sediment of NSAS}

The concentrations of heavy metals in bed sediment decreased in the order $\mathrm{Zn}>\mathrm{Cr}>\mathrm{Cu}>\mathrm{Ni}>\mathrm{Pb}$. The results for CVs indicated that anthropogenic input was involved in enrichment of heavy metals in bed sediment, and decreased in the order $\mathrm{Cu}>\mathrm{Ni}>\mathrm{Cr}>\mathrm{Pb}>\mathrm{Zn}$.

Most of the sediment samples were neutral $\mathrm{pH}$. The $\mathrm{pH}$ was not a factor influencing distribution of heavy metals in bed sediment, while OM could influence distribution of heavy metals in bed sediment.

\subsection{Contamination Characteristics and Risk Assessment}

\subsubsection{Contamination Characteristics}

The results for EFs indicated that anthropogenic inputs contributed to enrichment of heavy metals in bed sediment. The contamination rates and anthropogenic inputs of single heavy metals decreased in the order $\mathrm{Cu}>\mathrm{Ni}>\mathrm{Pb}>\mathrm{Cr}>\mathrm{Zn}$, the highest rate and input of $\mathrm{Cu}$ were three times higher than the lowest rate and input of $\mathrm{Zn}$.

According to the results of $\mathrm{P}_{\mathrm{n}}$ index, the integrated pollution levels were greatly varied in different sampling sites, which was due to great variation in spatial distribution of heavy metals. Nine out of 29 sampling sites were exposed to low integrated pollution of all the heavy metals; 12 sampling sites were exposed to moderately integrated pollution; eight sampling sites had strongly integrated pollution. Generally, $72.41 \%$ of sampling sites were exposed to low to moderately integrated pollution, and $27.59 \%$ of sampling sites were exposed to strongly integrated pollution. Spatially, the pollution sources from Songhua River posed a potential pollution risk to NSAS, and the lowest integrated pollution levels occurred in the largest branch of NSAS where tourism had not been developed.

\subsubsection{Risk Assessment}

The results for ER indicated that ecological risks of single heavy metals in all the sampling sites were low, and ecological risk levels of five heavy metals decreased in the order $\mathrm{Cu}>\mathrm{Ni}>\mathrm{Pb}>\mathrm{Cr}>\mathrm{Zn}$.

The results for PERI suggested that all the sampling sites were exposed to low comprehensive ecological risks of all the heavy metals. Among 29 sampling sites, the comprehensive ecological risks of all the heavy metals were the lowest in the largest branch of NSAS, which was an undeveloped-tourism area. The highest comprehensive ecological risks existed in inflow-river area, which might be attributed to high anthropogenic inputs of heavy metals into Songhua River. The comprehensive ecological risk downstream of Songhua River was low. This could lead to the conclusion that tourism in NSAS did not pose ecological risks with heavy metals downstream of Songhua River.

Results for HQs and HIs indicated that the exposure of all the heavy metals to bed sediment through ingestion and dermal contact posed no or little risks to human health. All the sampling sites exposed no or little human health risks of each heavy metals in bed sediment. Among five heavy metals, human health risks through the pathways of ingestion and dermal contact both decreased in the order $\mathrm{Cr}>\mathrm{Pb}>\mathrm{Ni}>\mathrm{Cu}>\mathrm{Zn}$, with exposures of $\mathrm{Cr}$ and $\mathrm{Pb}$ to bed sediment posed greater risks to human health. The pathway of ingestion significantly contributed to human health risks of heavy metals in bed sediment.

\section{Conclusions}

The results obtained in this work offer information on concentration levels, contamination characteristics, and ecological and human health risks of heavy metals in bed sediment of NSAS. The concentrations of $\mathrm{Zn}, \mathrm{Cr}, \mathrm{Pb}, \mathrm{Ni}$ and $\mathrm{Cu}$ were determined in a total of 29 bed sediment samples. The results show that mean values of $\mathrm{Zn}, \mathrm{Cr}, \mathrm{Pb}, \mathrm{Ni}$, and $\mathrm{Cu}$ were 92.69, 90.73, 38.29, 46.77 and $49.44 \mathrm{mg} / \mathrm{kg}$, respectively. According to the results of EFs, contamination rates and anthropogenic inputs of single heavy metals decreased in the order $\mathrm{Cu}>\mathrm{Ni}>\mathrm{Pb}>\mathrm{Cr}>\mathrm{Zn}$; the results of $\mathrm{P}_{\mathrm{n}}$ index 
indicated that integrated pollution of all the heavy metals in $72.41 \%$ of sampling sites were low to moderate, and integrated pollution in $27.59 \%$ of sampling sites were strong. Results for PERI indicated that ecological risks of single and all the heavy metals in bed sediment from all the sampling sites were low. The results of HQs and HIs suggested exposures of heavy metals to bed sediment posed no or little risks to human health, and the pathway of ingestion significantly contributed to human health risks.

Acknowledgments: This work was supported by the Joint Research on the Sustainable Utilization for the Water and Resources Management of the Upper Reaches of the Yangtze River of China under Grant No. 2012DFG91520 and the Simulation Study of Yangcheng Lake Flow Field and Concentration Field of Beijing-Shanghai High-speed Railway of China under Grant No. 2010G029D2.

Author Contributions: Yongsheng Fu provided funding; Li Wan wrote the article, designed the experiments and participated in taking samples and all the experiments; Liang Xu participated in treatment of bed sediment samples and determining the concentrations of heavy metals.

Conflicts of Interest: The authors declare no conflict of interest.

\section{References}

1. Ata, S.; Rahimeh, S.; Behzad, M. Contamination, toxicity and risk assement of heavy metals and metalloids in sediments of Shahid Rajaie Dam, Sefidrood and Shiringrood Rivers, Iran. Environ. Earth Sci. 2016, 75, 679.

2. Gao, J.M.; Sun, X.Q.; Jiang, W.C.; Wei, Y.M.; Guo, J.S.; Liu, Y.Y.; Zhang, K. Heavy metals in sediments, soils, and aquatic plants from a secondary anabranch of the three gorges reservoir region, China. Environ. Sci. Pollut. Res. 2016. [CrossRef] [PubMed]

3. Liang, P.; Wu, S.C.; Zhang, J.; Cao, Y.; Yu, S.; Wong, M.H. The effects of mariculture on heavy metal distribution in sediments and cultured fish around the Pearl River Delta region, south China. Chemosphere 2016, 148, 171-177. [CrossRef] [PubMed]

4. Chen, W.W.; Zhang, J.X.; Abass, O.K.; Wen, X.Y.; Huang, H.F.; Qu, C.K.; Qi, S.H. Distribution characteristics, concentrations, and sources of $\mathrm{Cd}$ and $\mathrm{Pb}$ in Liaoxiawan Channel Sediments from Zhuzhou, China. Bull. Environ. Contam. Toxicol. 2016. [CrossRef]

5. Yang, Y.; Zhou, Z.C.; Bai, Y.Y.; Chen, W. Risk assessment of heavy metal pollution in sediments of the Fenghe River by the fuzzy synthetic evaluation model. Pedosphere 2016, 26, 326-334. [CrossRef]

6. Deng, J.; Wang, Y.; Xin, L.; Hu, W.; Zhu, J.; Lin, Z. Spatial distribution and risk assessment of heavy metals and as pollution in the sediments of a shallow lake. Environ. Monit. Assess. 2016, 188, 296. [CrossRef] [PubMed]

7. Ali, M.M.; Ali, M.L.; Islam, M.S.; Rahman, M.Z. Preliminary assessment of heavy metals in water and sediment of Karnaphuli River, Bangladesh. Environ. Nanotechnol. Monit. Manag. 2016, 5, 27-35. [CrossRef]

8. Sun, C.Y.; Zhang, J.Q.; Ma, Q.Y.; Zhang, F.; Chen, Y. Risk assessment of polycyclic aromatic hydrocarbons (PAHs) in sediments from a mixed-use reservoir. Hum. Ecol. Risk Assess. 2016, 22, 447-459. [CrossRef]

9. Tzorki, O.; Karaouzas, I.; Patroecco, L.; Skoulikidis, N.; Nikolaidis, N.P. Polycyclic aromatic hydrocarbons (PAHs) and heavy metal occurrence in Bed Sediments of a Temporary River. Water Air Soil Pollut. 2015, 226, 421. [CrossRef]

10. Bing, H.J.; Zhou, J.; Wu, Y.H.; Wang, X.; Sun, H.; Li, R. Current state, sources, and potential risk of heavy metals in sediments of Three Gorges Reservoir, China. Environ. Pollut. 2016, 214, 485-496. [CrossRef] [PubMed]

11. Gabriel, G.; Cristian, P.; Florin, B.; Anca, E.G.; Marina, S. The ecological risk of heavy metals in sediment from the Danube Delta. Ecotoxicology 2016, 25, 688-696.

12. Tang, W.Z.; Duan, S.H.; Shan, B.Q.; Hong, Z.; Zhang, W.Q.; Yu, Z.; Chao, Z. Concentrations, diffusive fluxes and toxicity of heavy metals in pore water of the Fuyang River, Haihe Basin. Ecotoxicol. Environ. Saf. 2016, 127, 80-86. [CrossRef] [PubMed]

13. Efren, G.O.; Jose, M.E.; Stefano, C.; Miguel, A.L.-B.; Pablo, L.H.; Jorge, L. Heavy metal contamination in sediments of an artificial reservoir impacted by long-term mining activity in the Almaden mercury district (Spain). Environ. Sci. Pollut. Res. 2016, 23, 6024-6038. 
14. Zheng, B.H.; Qin, Y.W.; Zhang, L.; Ma, Y.; Zhao, Y.; Wen, Q. Sixty-year sedimentary records of polymetallic contamination $(\mathrm{Cu}, \mathrm{Zn}, \mathrm{Cd}, \mathrm{Pb}, \mathrm{As})$ in the Dahuofang Reservoir in Northeast China. Environ. Earth Sci. 2016, 75, 486. [CrossRef]

15. Malgorzata, W.; Jan, B.; Anna, W. Assessment of the hazard posed by metal forms in water and sediments. Sci. Total Environ. 2016, 551-552, 387-392.

16. Lei, P.; Zhang, H.; Shan, B.Q.; Lv, S.; Tang, W. Heavy metals in estuarine surface sediments of the Hai River Basin, variation characteristics, chemical speciation and ecological risk. Environ. Sci. Pollut. Res. 2016, 23, 7869-7879. [CrossRef] [PubMed]

17. EPAC, 1997a. Soil Quality, Determination of Copper, Zinc-Flame Atomic Absorption Spectrophotometry (GB/T 17138-1997). Available online: http://kjs.mep.gov.cn/hjbhbz/bzwb/trhj/trjcgfffbz/199805/ t19980501_82031.htm (accessed on 12 May 2016).

18. EPAC, 1997b. Soil Quality, Determination of Lead, Cadmium—Graphite Furnace Atomic Absorption Spectrophotometry (GB/T 17141-1997). Available online: http://kjs.mep.gov.cn/hjbhbz/bzwb/trhj/ trjcgfffbz/199805/t19980501_82029.htm (accessed on 13 May 2016).

19. Schnitzer, M. Total carbon, organic matter, and carbon. In Methods of Soil Analysis; American Society of Agronomy: Madison, WI, USA, 1982; pp. 539-577.

20. Lofrano, G.; Libralato, G.; Alfieri, A.; Carotenuto, M. Metals and tributyltin sediment contamination along the Southeastern Tyrrhenian Sea coast. Chemosphere 2016, 144, 399-407. [CrossRef] [PubMed]

21. Liu, Q.; Wang, Y.; Liu, J.S.; Wang, Q.; Zou, M. Grain-size distribution and heavy metal contamination of road dusts in urban parks and squares in Changchun, China. Environ. Geochem. Health 2015, 37, 71-82.

22. He, D.; Shi, X.M.; Wu, D.Y. Particle-size distribution characteristics and pollution of heavy metals in the surface sediments of Kuitun River in Xinjiang, China. Environ. Earth Sci. 2016, 75, 104. [CrossRef]

23. Ma, L.; Sun, J.; Yang, Z.G.; Wang, L. Heavy metal contamination of agricultural soils affected by mining activities around the Ganxi River in Chenzhou, Southern China. Environ. Monit. Assess. 2015, 187, 731. [CrossRef] [PubMed]

24. Li, Q.; Ji, H.B.; Qin, F.; Tang, L.; Guo, X.; Feng, J. Sources and the distribution of heavy metals in the particle size of soil polluted by gold mining upstream of Miyun Reservoir, Beijing: Implications for assessing the potential risks. Environ. Monit. Assess. 2014, 186, 6605-6626. [CrossRef] [PubMed]

25. Wang, Y.B.; Chen, W.L.; Wang, S.W. Characterization of heavy-metal-contaminated sediment by using unsupervised multivariate techniques and health risk assessment. Ecotoxicol. Environ. Saf. 2015, 113, 469-476. [CrossRef] [PubMed]

26. USEPA. Risk Assessment Guidance for Superfund, Volume 1. Human Health Evaluation Manual (Part E); Report EPA/540/R/99/005; U.S. Environmental Protection Agency: Washington, DC, USA, 2004.

27. Iqbal, J.; Tirmizi, S.A.; Shah, M.H. Statistical apportionment and risk assessment of selected metal in sediments from Rawal Lake (Pakistan). Environ. Monit. Assess. 2013, 185, 729-743. [CrossRef] [PubMed]

28. Tang, Z.W.; Zhang, L.Z.; Huang, Q.F.; Yang, Y.F.; Nie, Z.Q.; Cheng, J.L.; Yang, J.; Wang, Y.W.; Miao, C. Contamination and risk of heavy metals in soils and sediments from a typical plastic waste recycling area in North China. Ecotoxicol. Environ. Saf. 2015, 122, 343-351. [CrossRef] [PubMed]

(C) 2016 by the authors; licensee MDPI, Basel, Switzerland. This article is an open access article distributed under the terms and conditions of the Creative Commons Attribution (CC-BY) license (http:/ / creativecommons.org/licenses/by/4.0/). 